Historic, Archive Document

Do not assume content reflects current scientific knowledge, policies, or practices. 



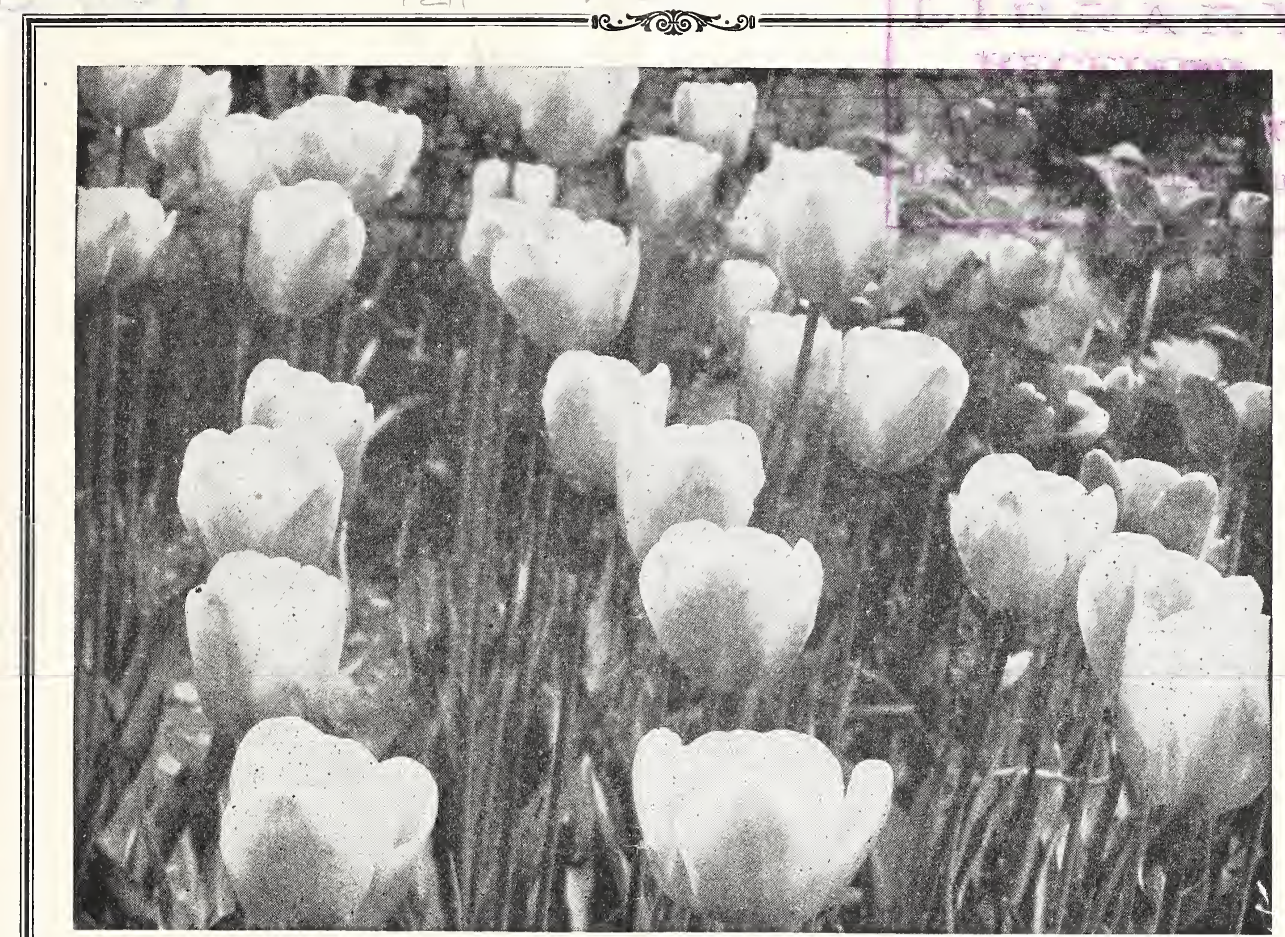

Darwin Tulips in bloom-Supplied in 511 colors

\section{Special Low Prices for DARWIN TULIP BULBS HIGH QUALITY DUTCH BULBS}

Fresh Fall Importation Direct From Grower To Us.

Mrs. J. B. Barnes, Casper, Wyo., writes "I wish to order 500 more tulip bulbs as described in your folder. I want to tell you about the wonderful tulips we had this Spring from bulbs purchased from you last Fall. Some grew to the extreme height of 32 inches. I was so pleased with them because we are about 6000 feet above sea level at our summer cottage and I was doubtful about them growing."

\section{Now for that Fall Garden of Spring Delights-Order now}

The same high class bulbs from the Select Your Varieties same high class Holland growers as we sold last year. Thousands of delighted customers this spring.

Miss Pearl Liedblad of 26 Cook Ave., Jamestown, N. Y., writes under date of June 3rd. "I have never seen more gorgeous or perfect tulips."

Mr. J. E. McIntosh, Hardware dealer, Heuvelton, N. Y., writes under date of June 11th. "Last year I bought 100 tulip bulbs for $\$ 3.50$. I never saw such wonderful tulips."

From the Following List:

Anton Roozen, bright rosy pink.

Glory, brilliant red, easy forcer.

Dream, beautiful soft lilac.

Glow, (Claude Gillot) vermillion scarlet, showy.

Yellow Darwin.

King Harold, purple-red, with white base.

Massachusetts, vivid pink, white center, large.

Mrs. Potter Palmer, deep purple, handsome form.

Painted Lady, creamy white, tinted heliotrope.

The Sultan, rich maroon black, blue base. 100 Bulbs for only $\$ 3.50 \_500$ Bulbs for only $\$ 16.50-1000$ Bulbs for only $\$ 30.00$ 


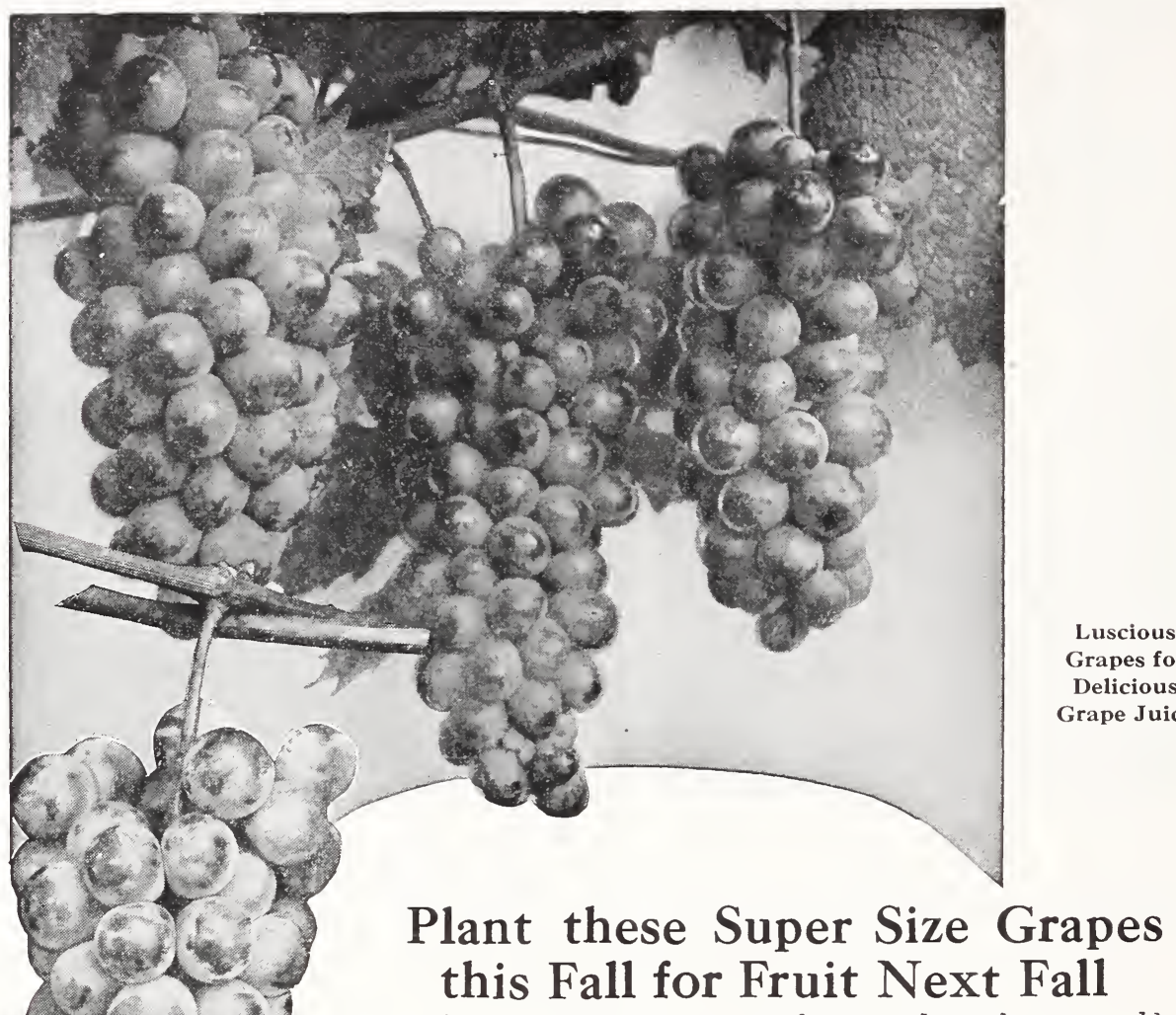

It's a fact you may now order extra large three year old grape vines that have actually produced bunches of fruit in the nursery row, in other words BEARING AGE VINES which, if planted this Fall, should produce fruit next year.

PRICE-\$1.00 each, \$10.00 per 12.

These vines are 3 years old and extra large.

\section{BEST VARIETIES FOR PRESSING JUICE OR EATING FRESH}

Concord, blue. Bunches compact; berries large, round, almost black; juicy and sweet; hardy and productive.

Moore's Early, blue. Bunches large; berries round, black with a heavy blue bloom. Healthy and hardy withstanding temperatures of 20 degrees below zero. Matures twenty days before Concord.

Ives, black. Bunch extremely large, handsome; berry-large, tender, juicy, rich, sweet, without pulp. Vine is vigorous, healthy, hardy.

Brighton, red. Bunches compact, shouldered; berries wine-red, purple bloom, tender, almost seedless, sugary and rich; about a week earlier than Delaware.

Jefferson, red. Bunches large, shouldered; berries bright red, tender, sweet, aromatic. Fine keeper and good market Grape.

Catawba, red. Bunches large, loose shouldered; berries coppery red, juicy sweet, slightly musky; vine productive.

Lucile, red. Bunches very large and compact, rich dark red, sweet and delicious; extremely hardyhealthy; bears tremendous crops. An indispensable variety for the far North.

Green Mountain, white. Bunches long, compact, shouldered; berries oval, greenish white, very sweet and rich; healthy and very productive.

Niagara, white. Bunches uniform and compact, pale yellow, with a thin white bloom; strong and very hardy. A little earlier than Concord.

\section{SPECIAL-NEW CHAMPAGNE GRAPE-2 Yr. Size Only}

A sterling variety of greatest merit. Color a beautiful copper red, berries very large-immense bearer. Champagne never having been known to winterkill, always producing an immense crop of fruit even:"during seasons when many other varieties fail to fruit. Champagne is a strong grower, 15 to 20 feet or more a season being common. The flesh is tender, extremely juicy and sweet with a rich aromatic flavor. Its keeping qualities are superior. Fine for eating fresh or grape juice. Order now for Fall planting as stock is limited.

PRICES-No. 1, 2 yr. extra strong $\$ 1.00$ each, $\$ 10.00$ per $12, \$ 65.00$ per 100. 


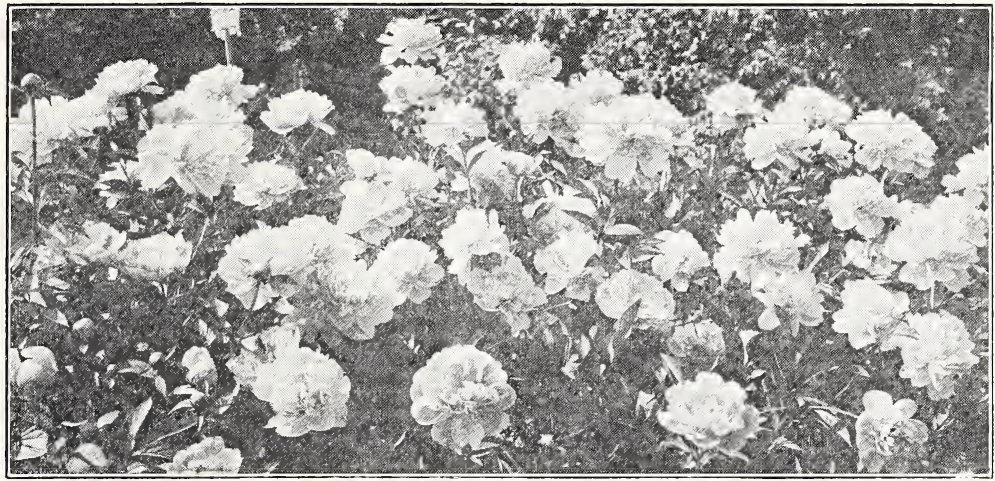

Planted this Fall will Bloom next Summer

\section{Peonies For Fall Planting}

Peony blooms retailed at local florists last June at 20c per bloom. We will sell you six strong roots that will produce scores of large and gorgeous blooms not only next Spring but each succeeding Spring for the small sum of $\$ 3.75$.

\section{Six All Different-You Can't Beat Them-only $\$ 3.75$ For Cut Flowers the Following Varieties are Excellent}

Canari. Yellowish; globular bomb type of medium size, fragrant; late.

Edulis Superba. Bright mauve-pink; large, rather flat, crown type; free-flowering; fragrant; medium early.

Marechal MacMahon. Rich, dark red; large, bomb type; a fine flower of rare beauty.

Mme. Calot. Pale hydrangea-pink, center shaded darker; large, rose type, free flowering; fragrant; early. Very good.

\section{Iris For Bloom Next June}

At Prices You Can Afford to Pay

We offer a special assortment consisting of Japanese and Liberty Iris, each order containing an assortment of varieties and colors at the following low prices.

\section{0 roots $\$ 1.00$ \\ 100 roots 9.00 \\ 1000 roots 75.00}

Order generously - plant them in shrub borders, along the walks and driveways, on the banks of streams, small lakes and ponds plant them anywhere and everywhere. One dollar, ten dollars one hundred dollars spent for these Irises will give you heaps of real pleasure and satisfaction.

Plant them this Fall and enjoy their exquisite beauty next June.
Festiva Maxima. Pure white, flecked with carmine; very large, rose type; free: flowering; fragrant; medium early.

L'Eclatante. Brilliant red; very large bomb type; strong-growing; midseason.

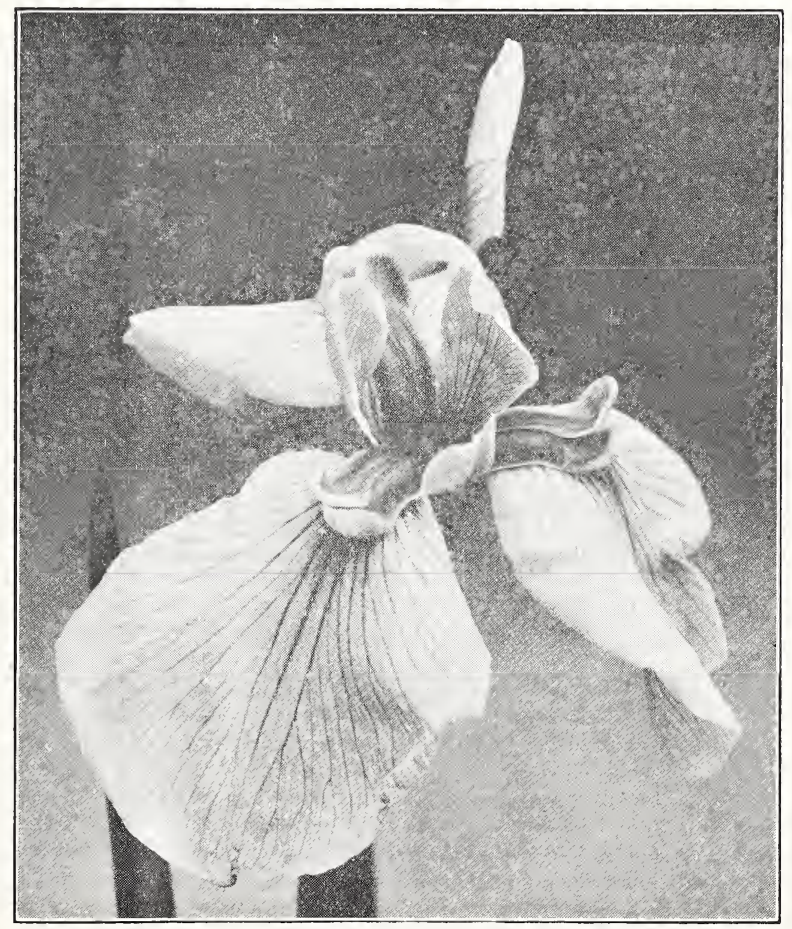

Plenty of Bloom Next Summer From Plants You Set This Fall 


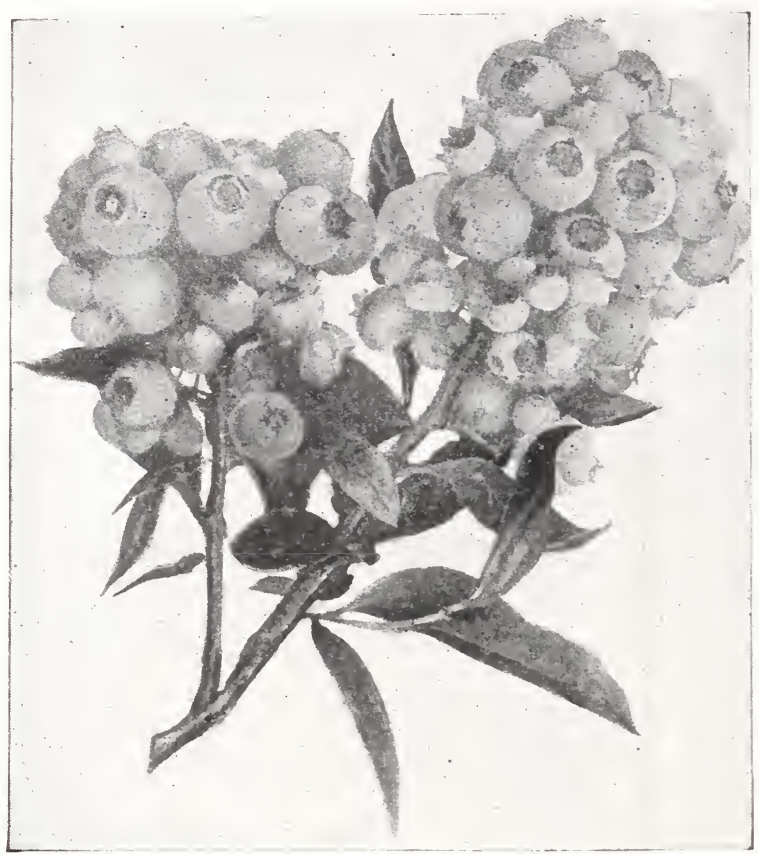

One quart of fruit sufficient for one big juicy pie.

Our plants are strong and bushy, 2-3 feet tall, especially selected, collected plants and have already produced fruit. Price $\$ 1.50$ each. $\$ 15.00$ per 12 .

\section{Erskine Park Everbearing Red Raspberry}

Its delicious fruit may be picked every day from June until frost. Think of it. Large, red, luscious Raspberries on your table every day during four months of the year and from your own garden. As late as November 20th, we have cut branches from plants growing in the nursery, with BLOSSOMS, GREEN FRUIT and RIPE FRUIT upon them. It should be planted in every garden and especially do we recommend planting the Erskine Park in large quantities where a suitable market for the fruit is available. We have a large, fine stock of 2 year old fruiting transplants for shipment at the proper time for planting this Fall.

The Erskine Park is perfectly hardy, withstanding the severest winters without injury. Plants set out this Fall will produce an abundance of fruit next summer. Price for heavy, 2 year old, fruiting transplants, $\$ 3.00$ per doz.; $\$ 20.00$ per 100 ; $\$ 150.00$ per 1000 .

Don't forget to add a few Hyacinth bulbsColors white, pink, yellow, red and blue. Large bulbs. $\$ 3.00$ per doz., $\$ 2.00$ per 6 .

\section{Ye Old Fashion Blueberries}

\section{Blueberry Plants for Your Own Garden}

CAN you imagine anything more satisfactory than having delicious blueberries growing in your own garden? No doubt you have enjoyed these wonderful fruits on the hotel or restaurant menu, served with cream for breakfast, or as blueberry pie or dumplings for luncheon or dinner. They are a fruit that satisfies for three meals a day and one dozen plants are quite sufficient to supply the average family with blueberries. They can be used freely for making breakfast muffins or preserves.

Blueberries require an acid soil to produce the best results. This is prevalent in many sections of the country. Where your soil is not acid, we suggest the following method to get the most from your plants. Choose a welldrained location, easily supplied by water during the dry summer months. Blueberries do best with full sun, although they will grow and produce fruit in partial shade. In order to get the proper acid condition to your soil. mix partly rotted leaves with the soil of your garden.

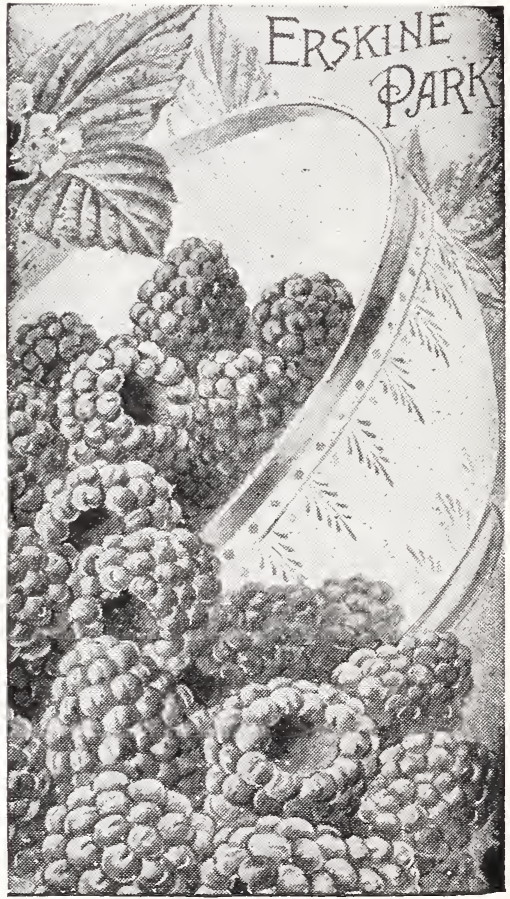

The "dessert berry of the Nation." 


\section{Delicious Washington Asparagus}

\section{Extra Large, 3 year old roots for cutting next season.}

You risk nothing. If upon receipt of shipment you find that the plants are not the finest and largest 3 year asparagus roots you have ever seen, wrap them up and return to us, and we will refund your money without question, quibble or controversy.

The New Rust Resisting Variety Developed by the United States Department of Agriculture

Washington Asparagus is the first result of a blister proof campaign for the eradication of asparagus rust and is as far as possible an extremely resistant, vigorous, and high yielding strain of giant asparagus.

For quick results plant these extra heavy roots 3 years old

Prices: $\$ 7.00$ per 100 , $\$ 30.00$ per $500, \$ 55.00$ per 1000 .

Free Asparagus Knife With each order for 500 plants. We will send free this Asparagus Cutting Knife.



\section{Burbank Giant \\ Crimson Rhubarb} A Luther Burbank Creation

H XTRA large, of fine bloom, E and crimson clear through, this new variety of appetizing "pie-plant" should be in every garden, and will be when known. Plant a few this Fall along beside that you now have growing in your garden and note the difference. Burbank Giant Crimson is superior in size and quality to any variety we have ever

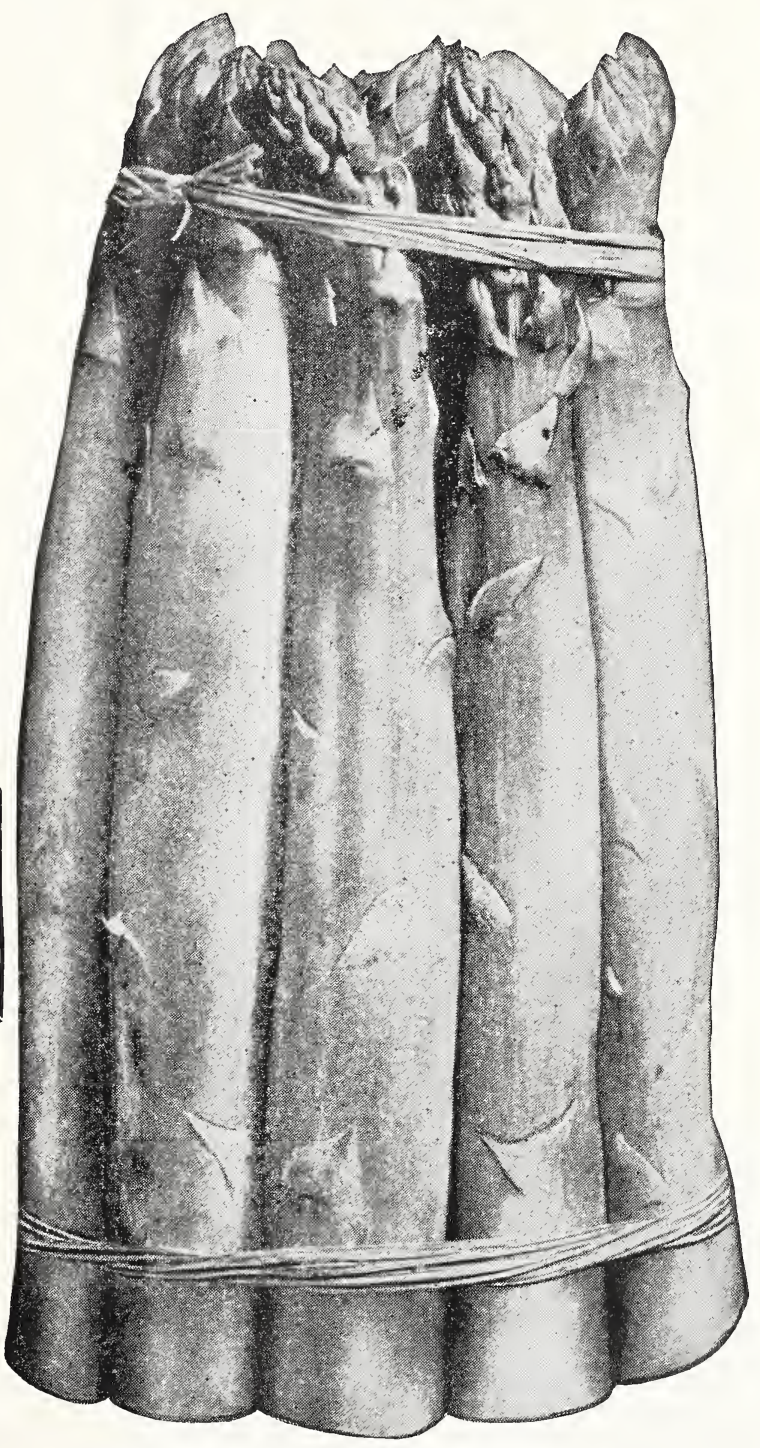

Why pay fancy prices for Asparagus-Grow your own.

tested. It is an early variety, without being in the least tough or stringy, with a mild sub-acid flavor. Largest and best of all for market or home use.

Plant this Fall in good garden soil, manure well, and have delicious pie and sauce next Spring.

Price-For strong roots, 2 years old, $\$ 1.50$ per $6, \$ 2.00$ per 12 . 



\section{REDUGED PRIGES ON LARGE SPEGIMEN FRUIT TREES}

\section{Trees 4 Years Old , Seven to Nine Feet Tall , Beautifully Rooted , Handsomely Branched}

$\$ 2.00$ each; $\$ 18.50$ per $10 ; \$ 150.00$ per 100

$\mathrm{F}_{\text {ALL is the real time to plant. The ground is in much better }}$ $\mathrm{F}$ condition in the Fall, being mellow and warm. Stock is completely dormant in the Fall, and, therefore, can be easily and safely handled, while in the spring the weather often comes of warm so early as to start the buds seriously before the customer an receive and plant his stock.

Many extensive and experienced planters, like the late horticultural writer, E. P. Roe, always prefer to plant in the Fal.

Shipment will be made at precisely the proper time for planting this Fall. Shipping notice will be mailed on date of shipment.
Order now today, while you have the matter fresh in your mind Order one tree or one thousand. Our 60 years experience is back of every tree.

\section{VARIETIES OF SUPER-SIZE} FRUIT TREES

\section{Luscious Apples for "Apple Jell"} Red Astrachan: Large; deep crimson; juicy. August.

Yellow Transparent: Medium size; pale yellow; good. July and August. Fameuse (Snow): Medium size; bright red; Alesb wbite. Juicy. October Gravenstein: Large; yellow overlaid with red; juicy, productive. Septem-

her to November
Twenty- Ounce (Cayuga Red Streak): Very large; yellow splashed with
red October. Baldwin: Larre; deep red; crisp and juicy; vigorous grower; heavy bearer.
Novemher to March. Delicious: Ranks high as a variety for commercial or bome orchards.
Large; hrilliant dark red; Alesh fine-grained, erisp, juicy. November to FebruMcIntosh: Large; deep red; fiesh crisp; tender, juicy. Octoher to December. rich, delicious. November to March
Rhode Island Greening: Large, greenish yellow; fesh tender. December Wealthy: Medium to large; deep red, juicy. October to January.

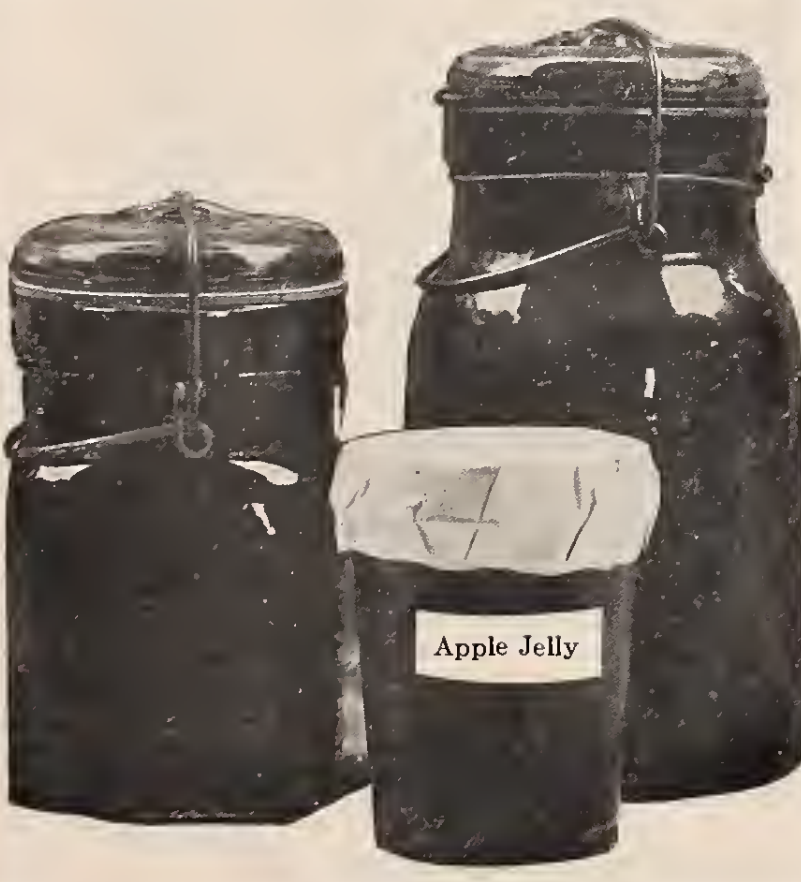

\section{Enlist in Our Army of Satisfied Customers Today}

ERNEST SPENGER

436 South 7 th Avenue, Mount Vernon, N. Y.

Messers. Glen Bros Rocbester, N. Y

December 5,1925

Gentlemen: The Lambert Cherry Tree was planted in 15 minutes after I received it and four guy wires placed to steady it so the whe and storn wh not move it. The tre Gage Plum, something most heautif ul, and very large in size and the three applc trees, all
planted on arrival and braced for protection and a straw mulch will be placed around them Some time ago I purchased two quince, a cberry and a Hyslop Crab Apple tree from ip at all. The thank you over and over as the trees are loa I stand sometimes and think of you and I am ever so tharkf unul that I hought from yo Let me tbank you again and will recommend you whenever possible. Yours truly, ERNEST SPENCER

\section{MONEY BACK GUARANTEE}

Money back if not perfectly satisfied, providing trees are returned properly packed same day as received. You couldn't ask for anything fairer than this.

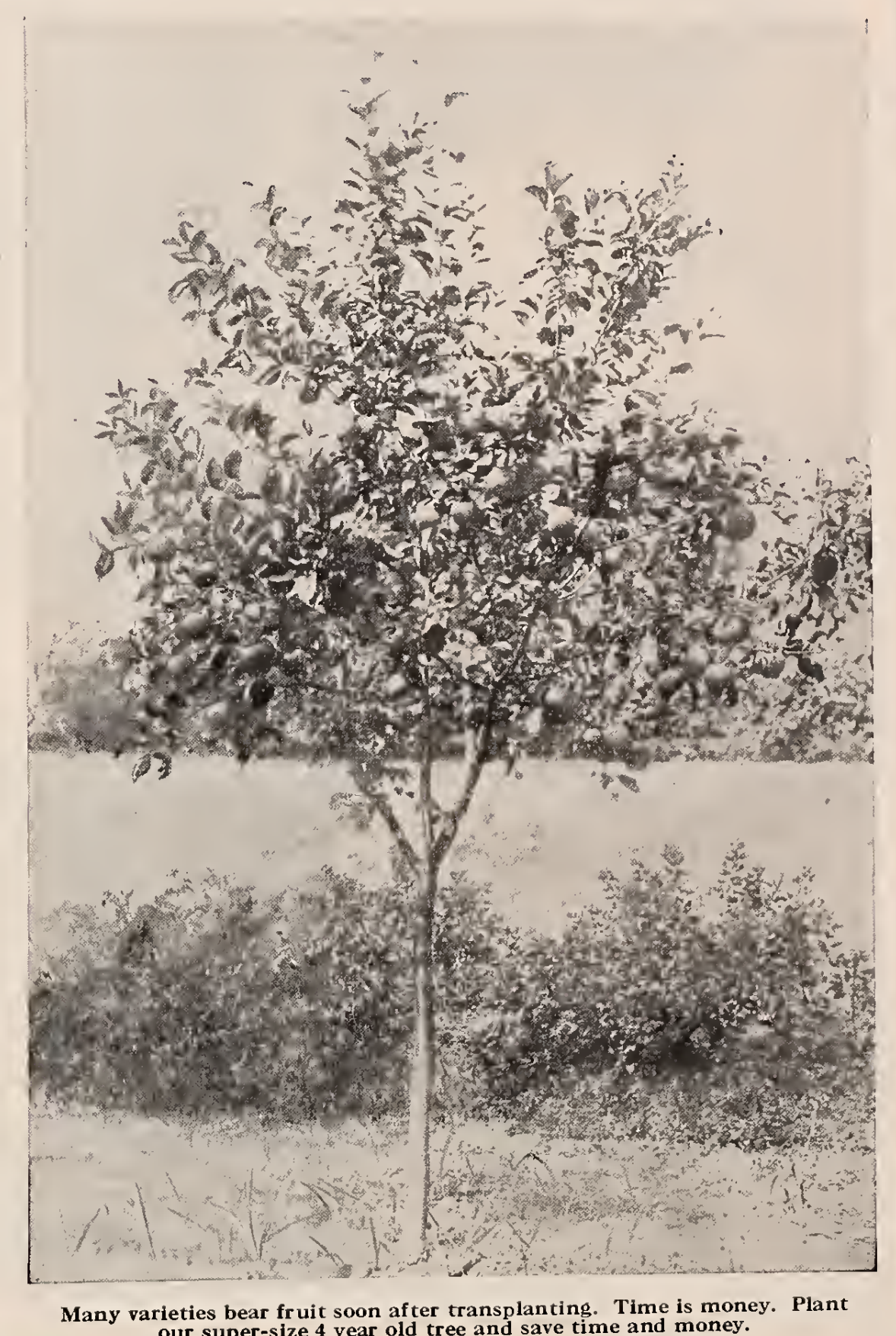

Many varieties bear fruit soon after transplanting. Time is money. Plan 


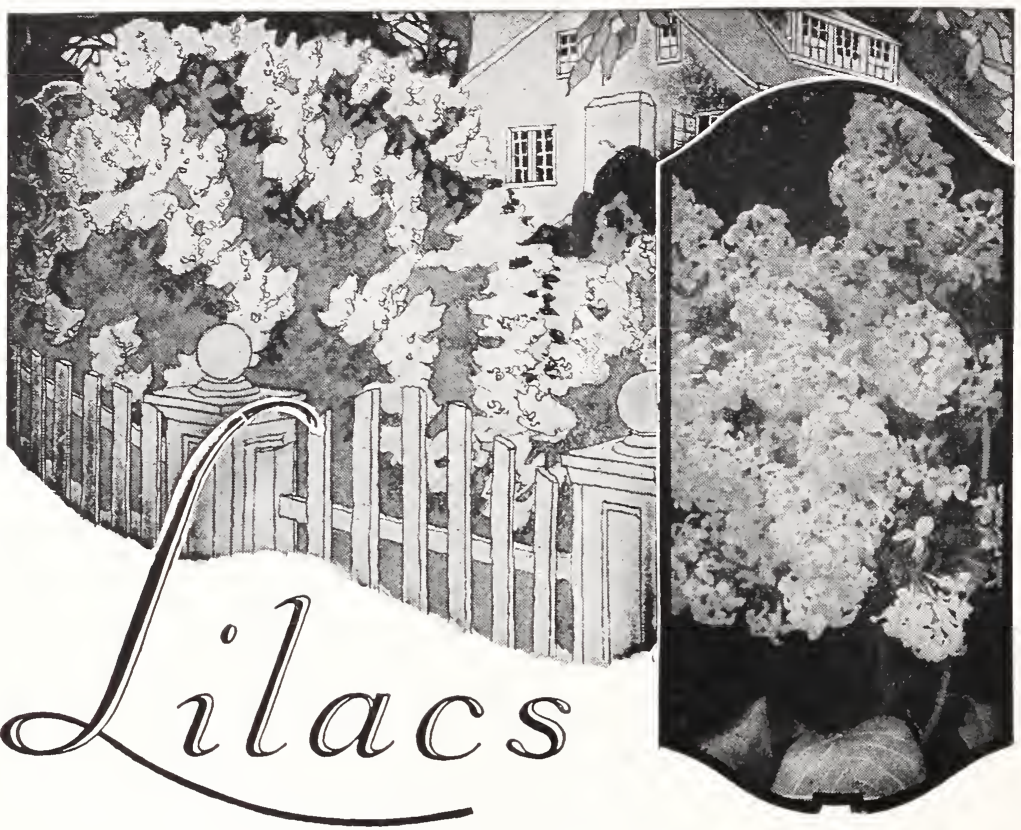

A Magnificent Flower Show

9 CIS true we are selling for this Fall's planting only, this selection of six magnificent French

1 hybrid lilacs for $\$ \mathbf{6 . 0 0}$. Strong plants $2-3 \mathrm{ft}$. in height, planted this Fall should bloom next season. Only one thousand of these collections will be sold at this price.

Belle de Nancy: Double. Great panicles of pink flowers with white center.

Congo: Single. Flowers a beautiful deep wine-red.

President Grevy: Double. Beautiful lilac-blue flowers in huge panicles.

You may never again have an opportunity to purchase these six wonderful lilacs at this remarkably low price. Order immediately as no orders will be received at this price after the one thousand collections have been sold.

\section{Choice Lilies}

QPECIAL collection of six varieties best $\checkmark$ hardy lilies $\$ 3.00$. No class of plants capable of being cultivated out of doors possesses so many charms. Rich and varied in color-stately and handsome in habit-profuse in variety-fragrant.

Madonna Lily: The old fashioned pure white garden lily. One of the hardiest.

Auratum Lily: (Gold-banded lily of Japan). Flowers very large, delicate ivory white color thickly dotted with rich chocolate crimson spots with the bright golden bands through the center of each petal. The finest of all lilies.

Tiger Lily: Bright orange scarlet with dark spots. A strong growing, showy variety and entirely hardy. Succeeds well everywhere.

Superbum: Averages from 3 to $6 \mathrm{ft}$. in height. Its nodding crests adding to the general brilliancy of July with from 5 to 40 handsome orange red blossoms.

Speciosum Album: Pure white with a green band traversing the center of each petal.

Henryi: (Yellow Speciosum). One of the finest hardy lilies of strong, vigorous growth with flower stalks 3 to $5 \mathrm{ft}$. long. Deep apricot yellow, light and spotted brown.

This splendid collection of six large size bulbs only $\$ 3.00$
Mme. Abel Chatenay: Double. Sweetly scented pure white flowers in large panicles.

Charles X: Single. Strong, rapid grower; rather loose trusses of reddish purple flowers.

Leon Simon: Double large flowers of a purplish crimson shade.

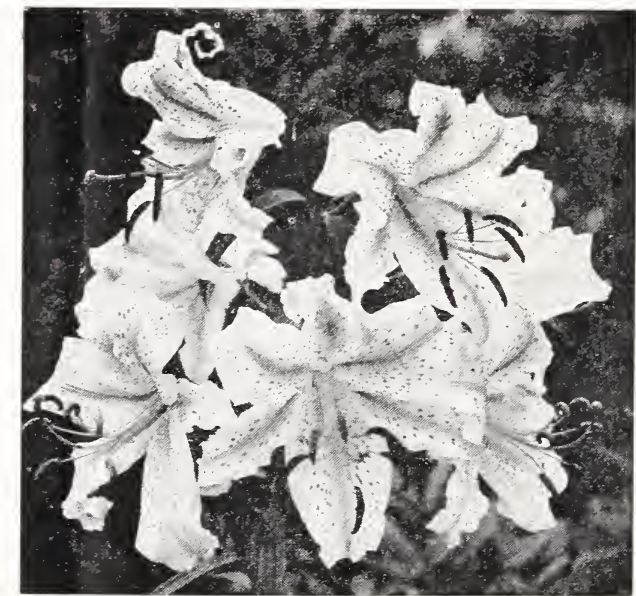

Fine for Shrub Border or in Beds 


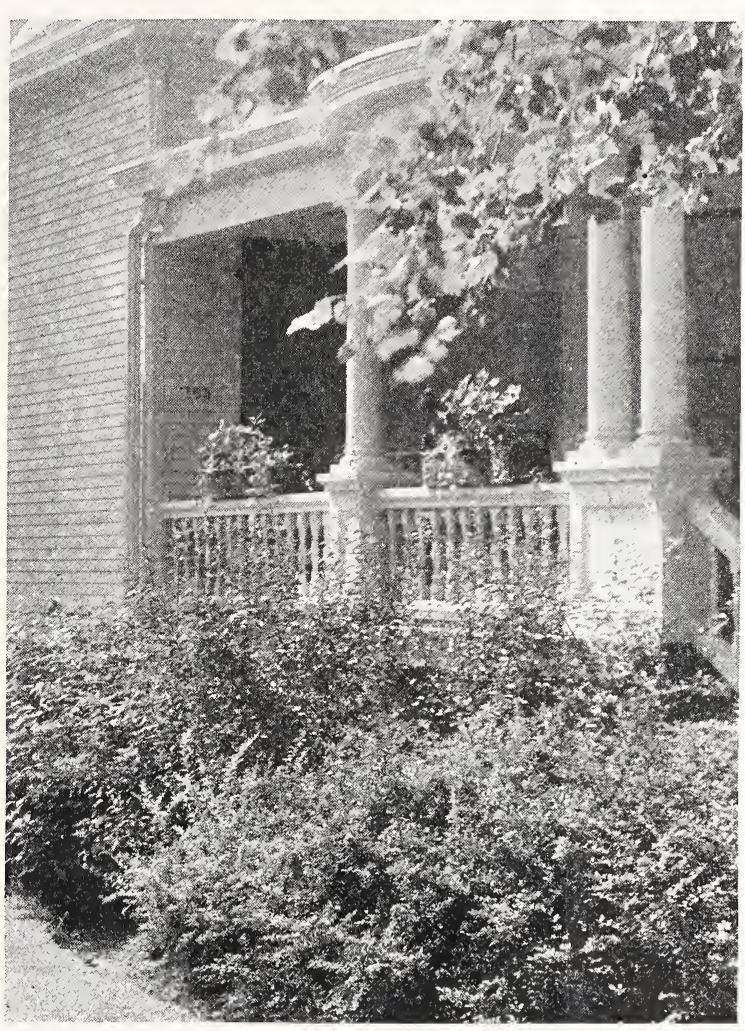

A splendid showing at small cost

\section{Beautiful} Shrubs for Blooming Next Summer if Planted this Fall

This is the collection you have been wanting to order - large, bushy shrubs, two year old plants.

Twelve of them, all different, for only $\$ 5.00$

\section{Plant More Flowering} Shrubs

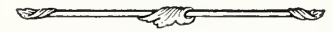

Tartarian Upright Honeysuckle: Bears a profusion of bright pink flowers in the spring, followed by orange scarlet berries.

Siberian Pea Shrub: A large shrub with compoundleaves, consisting of 8 to 12 bright green leaflets. Native of Siberia. Flowers yellow, in numerous small clusters, in late spring.

Butterfly Bush: (Summer Lilac). The name Butterfly Bush was applied to it because it seems to attract the large, gorgeously colored butterflies that swarm about it as though vieing with it in brilliancy of color. A single plant this season will throw out as many as 50 flower spikes.

Red Barked Dogwood: Spreading Shrub, 8 to 10 feet tall, with purple or dark blood-red branches, deep green leaves that are hairy on both sides, and greenish white flowers in flattopped clusters, berries black.

Coral Berry: The conspicuous ornamental feature of this plant is the wealth of plump red fruits that are clustered along the arching branches until late winter.

Spirea Van Houttei: Better known and more largely planted than any other shrub. An extremely graceful shrub with long, drooping branches completely covered with flat clusters of white flowers in May and June. Cannot be too highly recommended. We consider it the best general-purpose shrub. Grows 6 to 8 feet high.
Forsythia: (Golden Bell). Rich golden yellow flowers are borne in great profusion along the branches before the leaves appear.

Hydrangea Hortensis: An upright shrub, usually 4 to 8 feet tall, with bright green leaves. Flowers creamy white, generally with a few sterile rays, borne in numerous flat-topped clusters in early summer. Hardy and attractive.

Yucca: (Adam's Needle). A handsome evergreen plant with swordlike foliage, with spikes of fragrant drooping bell-shaped creamy white flowers during June and July, making a tropical effect.

Sweet Syringa: Popular ornamental deciduous shrub that will add attractiveness and fragrance to the home gardens.

Deutzia Pride of Rochester: A shrub that delights the eye with its large double white flowers which are tinged with pink in the bud.

White Tartarian Honeysuckle: A beautiful white variety with a profusion of bright red berries ripening in summer and persisting until Autumn.

\section{Shrubs - All Different - Fall is the Proper Time to Plant Them}




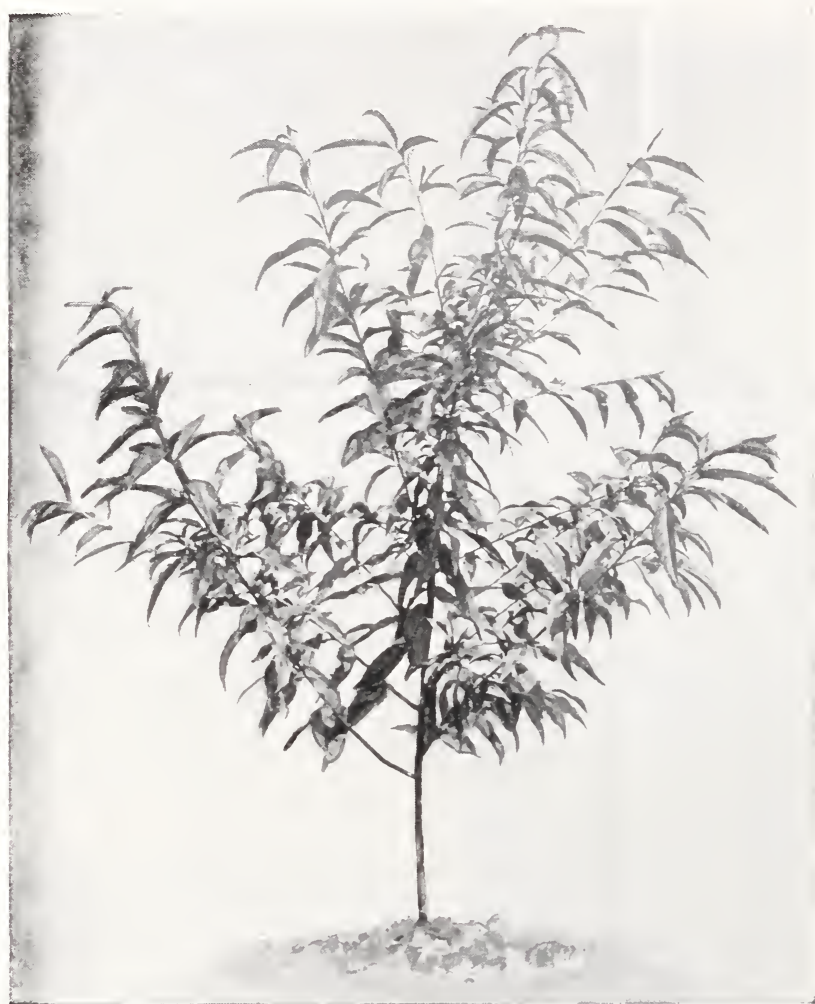

Blood Leaf Peach-Brilliant Red Bark, Dark Red Foliage Handsome pink blossoms in profusion in early Spring Plant as an ornamental, also for its fine fruit

\section{A Collection of 3 Beautiful Dwarf Orna- mentals for the Lawn for Fall Planting.}

Extremely Attractive

1 Blood Leaf Peach: Of this remarkable variety "PEACHES OF NEW YORK" by Professor U. P Hedrick. Vice Director and Horticulturist of the New York State Agricultural Experiment Station says "Blood leaf is a handsome ornamental, its beetred leaves in early Spring and its pink blossoms borne in great profusion entitle it to esteem for both foliage and flowers. It is worth growing as well as for its fruits." Plant it on the lawn, in your shrub border or in the garden.

1 Purple Leaved Plum: Small, compact-growing ornamental trees that will prove effective as a part of any planting scheme. The foliage is dark crimson, changing to purple as it matures, retaining that color until late in November.

1 Japanese Flowering Quince: In early Spring the branches are hidden by the wealth of dazzling scarlet flowers which are borne in great profusion. The quinceshape fruits which follow are rather fragrant. One of the best hardy shrubs grown.

We offer this Collection of 3 for $\$ 3.50$

\section{A Fall Special of 3 Delightful Vines, All Different for $\$ 2.00$}

1 Wisteria: Picturesque climber with great clusters of pale bluish violet, pea-shaped flowers that make a handsome showing when a vine has been properly trained over a porch or arbor. After becoming established, the vine makes an enormous annual growth.

1 Hall's Honeysuckle: Evergreen climber with deliciously fragrant white flowers that change to yellow.

1 Evergreen Bittersweet: A beautiful, lowtrailing evergreen with aerial rootlets which cling to any support. Forms a lovely decoration on walls or trees, with its masses of red berries in winter. As an evergreen, absolutely hardy wall cover, this plant is unequalled.

\section{Al1 3 for $\$ 2.00$}

Vines are completely dormant in the Fall, and, therefore, can be easily and safely handled, while in the Spring the weather often comes off warm so early as to start the buds seriously before the customer can receive and plant them.

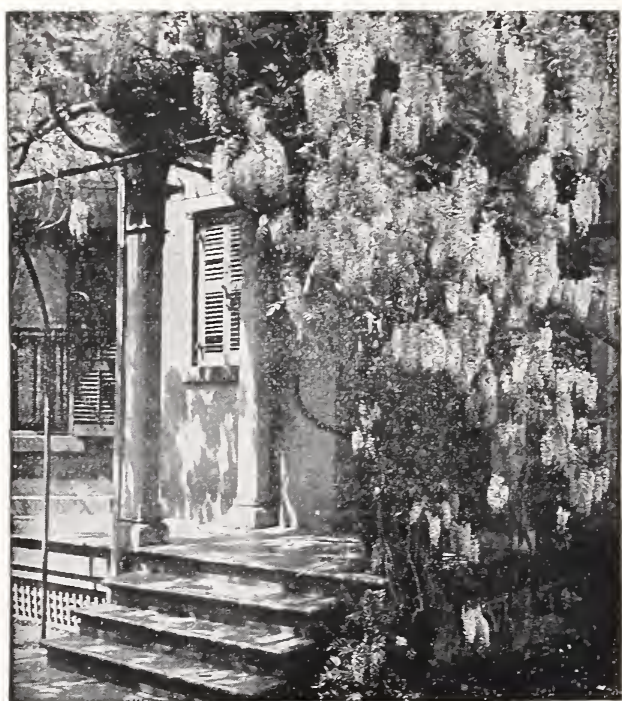

Great clusters of light bluish-violet pea-shaped flower give the Wisteria a distinctive ornamental value. 


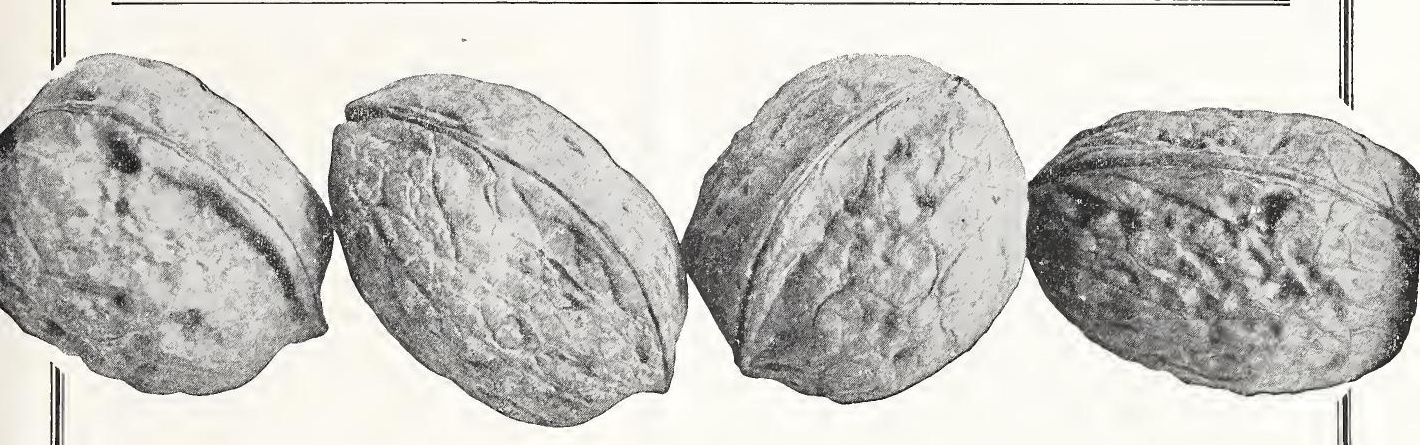

\section{Hardy English Walnut Trees}

\section{For Planting in All Localities, Even the Extreme North Where Winter Temperatures are Not Too Severe for Peach or Cherry Trees}

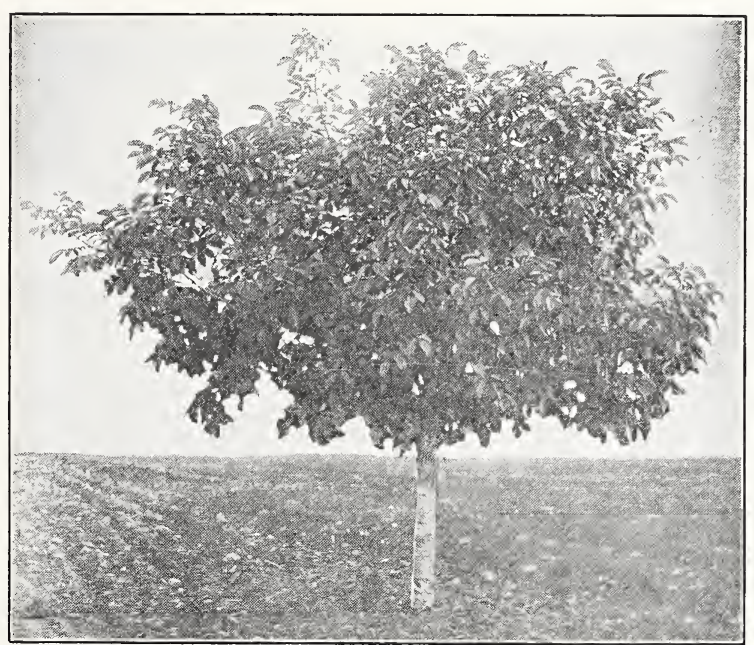

8 Year Old Bearing English Walnut at Glenwood Nursery

The trees that we offer bear in cold New England. Read Mr. Avery's letter.

AVERY, KRETZMER, OLCOTT, Inc. Scales, Engines, Specialties 30 High Street Hartford, Conn.

March 11th, 1925.

Glen Brothers,

Rochester, N. Y.

Gentlemen:-

Will you please send me a copy of your latest catalogue?

It might interest you to know that some nine years ago I purchased several English Walnut trees from you, these trees have made a most satisfactory growth, and have borne a few nuts for the last three or four years. Last year four of them bore fruit of very good size and quality. One tree in particular bore some five or six quarts of very good nuts.

Have been quite pleased with the results from these trees.

Very truly yours,

(Signed) IRVING J. AVERY Wolcott Hill, Wethersfield, Conn.

Motor tourists visiting Rochester are cordially invited to visit Glenwood Nursery on any week day and inspect our trees.

English Walnut: Every English Walnut tree we sell was started from seed produced from a bearing tree growing in this localityevery tree guaranteed is to be a "Glenwood Grown" tree, hence our trees are very hardy. Neither our young nursery trees nor our eight year old bearing trees have ever shown the slighest evidence of injury from winter temperatures of eighteen to 20 degrees below zero.

Plant a few of these trees this Fall. In your available space a few hardy, vigorous English Walnut trees will prove valuable for decoration, shade, and allow a household supply. The smooth bark is light gray in color, and the leaves are long, deep green and waxy. The English Walnut is a rapid grower and makes a desirable shade or lawn tree.

\begin{tabular}{|c|c|c|}
\hline \multicolumn{3}{|l|}{ Sizes and prices } \\
\hline Size & Each & Per 10 \\
\hline $2-3 \mathrm{ft}$. & $\$ 1.25$ & $\$ 10.00$ \\
\hline $3-4 \mathrm{f}$ & 1.50 & 12.50 \\
\hline $4-5 \mathrm{ft}$ & 2.00 & 18.00 \\
\hline $5-6 \mathrm{f}$ & 3.50 & 30.00 \\
\hline & 5.00 & 50.00 \\
\hline$-10 \mathrm{ft}$. specimens & 10.00 & 100.00 \\
\hline
\end{tabular}

We also have hardy trees of Butternuts, Black Walnuts, Filberts, Hickories, Almond, Japanese Walnut, etc. All are described with sizes and prices in our large 32 page general catalogue containing over fifty illustrations in actual, natural colors. Free for the asking. Ask for Catalogue "A". 


\section{Choice Hardy Roses For Only $\$ 8.00$}

Plant This Fall-Should Bloom Next June

Strong 2 Year Field Grown Blooming Plants

\section{HARDY VIGOROUS VARIETIES THAT ARE DEPENDABLE IN ALL PARTS OF THE UNITED STATES}

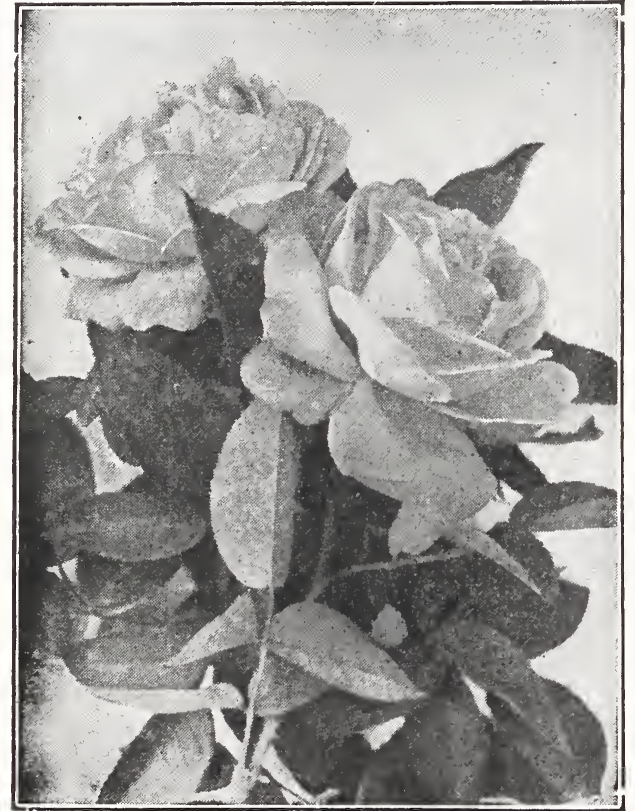

Where else can you get so much for so little?

1 American Beauty, red. Magnificent, large, globular flowers of a beautiful rosy crimson; delightfully fragrant.

1 Frau Karl Druschki, white. The buds are handsome, long-pointed, opening to very large pure snowy white cupped flowers of great substance. A very vigorous grower and exceptionally hardy: very free and continuous bloomer.

1 George Ahrends, pink. Also known as "Pink Druschki" In color, a fine rose pink; blooms full and double; of strong growth and free blooming habit.

1 Captain Christy, pink. Plump and heavy buds with backward-curling petals. Color light pink shaded dark. The large open bloom showing darker towards the center.

1 Heinrich Munch, pink. Delicate pink blooms, resembling those of the Frau Karl Druschki. The flowers are very large and full. A vigorous grower.

1 Jubliee, crimson. A true hybrid perpetual, perfectly hardy, blooming in fall as well as in early summer; bush vigorous, foliage dark green, an abundant bloomer; very large, reaching six inches across under high culture; color purest and deepest red, shading to deep crimson and velvety maroon.

1 Ulrich Brunner, crimson. Large cherrycrimson flowers of fine form. Very free flowering and vigorous. A fine all-purpose rose of standard excellence.

1 Magna Charta, pink . Large, full, well-formed flowers of bright pink; very fragrant. Exceedingly vigorous; fine for forcing under glass.

1 Persian Yellow. A Briar Rose with small deep golden yellow flowers of large size and fairly full. Vigorous grower

1 J. B. Clark, red. Intense deep scarlet, shaded blackish maroon, in exceedingly large and full blooms of moderate fragrance. Plant a rampant grower, blooming best in June, but sometimes repeating in the Fall.

\section{Hardy Chrysanthemums}

Bloom in the late Fall, when the "frost is on the pumpkin"

DLANT them outdoors this Fall and enjoy their exquisite blooms next October and November after all other outdoor flowers are gone. When in bloom are a perfect mass of flowers.

\section{Plant Each of Our 10 Favorites for $\$ 4.00$}

Boston: Bronze

Belden's: White

Red Button: Red

Firelight: Carmine, shaded garnet.

Harvest Home: Golden bronze.

Marie Antoinette: Rose.

Normandie: Early large light pink.

Petite Jean: Pinkish white.

Excelsior: Yellow.

White Dotte.

\section{Hardy Chrysanthemum} -Are a joy forever

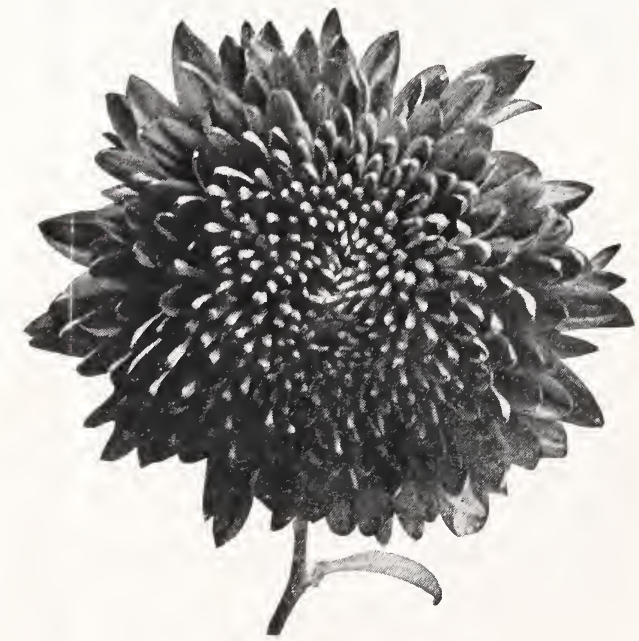

Beautiful Chrysanthemums on a cool fall morning. 